
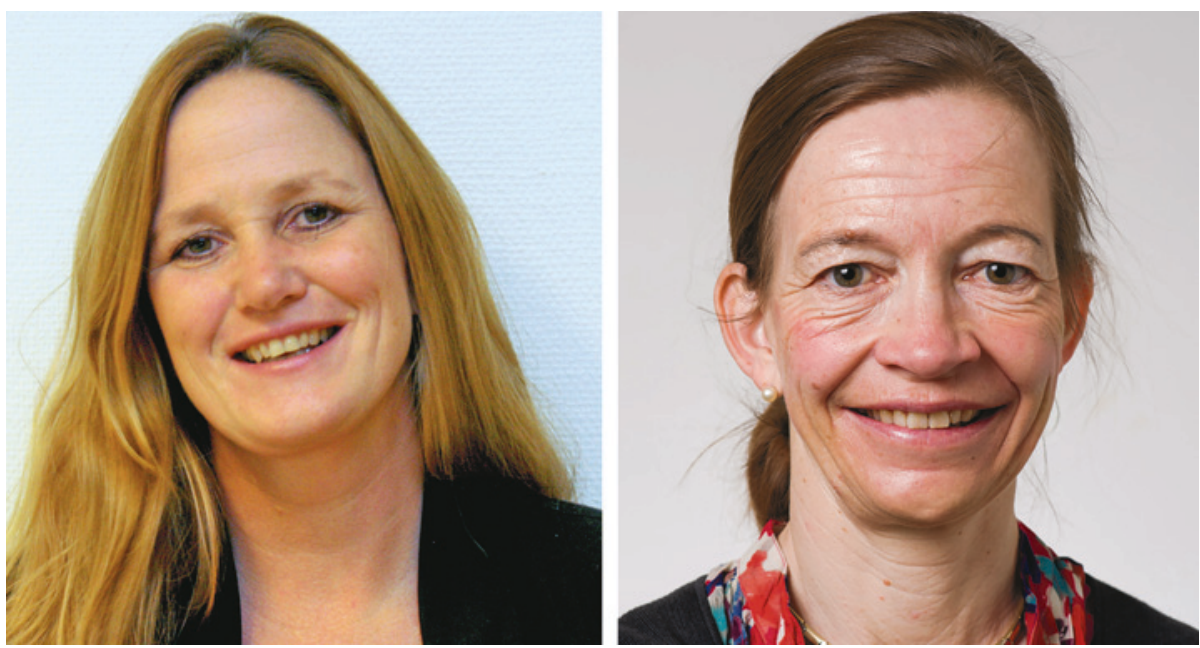

Marianne Løvstad, førsteforfatter (foto: Sunnaas sykehus), og professor Ellen-Cecilie Røe, Avdeling for fysikalsk medisin og rehabilitering. Oslo universitetssykehus, som ledet den nasjonale multisenterstudien (foto: Øystein H. Horgmo, Universitetet i Oslol

\title{
Langvarig bevissthetsforstyrrelse etter hodetraume er sjeldent
}

En norsk studie viser lav forekomst av pasienter i vegetativ eller minimalt bevisst tilstand etter traumatisk hjerneskade.

Moderne akutt- og intensivmedisin gir økt overlevelse av hardt skadede. Fører dette til mange tilfeller av vedvarende bevissthetstap etter hodetraumer? Norske forskere har nylig publisert en studie hvor de har undersøkt hvor mange pasienter som var i en vegetativ eller minimalt bevisst tilstand 3-36 måneder etter en alvorlig traumatisk hjerneskade (1).

Studien ble gjennomført som del av en nasjonal multisenterstudie som omfattet alle pasienter i Norge med alvorlig traumatisk hjerneskade i 2009-10. Forekomsten av bevissthetsforstyrrelser ble undersøkt ved bruk av et atferdsbasert kartleggingsverktøy. Det var totalt 359 pasienter med alvorlig traumatisk hjerneskade, hvorav 278 deltok i studien. Blant disse var det fem $i$ vegetativ tilstand og to i minimalt bevisst tilstand etter tre måneder. Etter 12 måneder var tallene henholdsvis tre og én, og det var ingen ytterligere endring etter 24-36 måneder. Insidensen av bevissthetsforstyrrelse etter alvorlig traumatisk hjerneskade var således 0,09 per 100000 innbyggere etter tre måneder og 0,05 etter 12 måneder.

- Sammenliknet med studier fra andre land er tallene våre lave, sier førsteforfatter Marianne Løvstad, som er spesialist i klinisk nevropsykologi ved Sunnaas sykehus og førsteamanuensis II ved Psykologisk institutt, Universitetet i Oslo. - Den rapporterte insidensen varierer mellom land, og vi vet ikke helt hvorfor. Dette er den første prospektive populasjonsbaserte studien som omfatter alle tilfeller $i$ et helt land og der moderne diagnostiske metoder er brukt, sier hun.

- Studien bidrar til bedre kunnskap om tilstandens epidemiologi. Dette er viktig med tanke på planlegging av behandlingstilbudet for slike pasienter, sier Løvstad. - I neste omgang er det ønskelig å få tilsvarende tall på bevissthetsforstyrrelser med andre årsaker enn traumatisk hjerneskade, så som oksygenmangel, hjerneblødninger og infeksjoner, sier hun.

\section{Norsk rehabiliteringssamarbeid}

Et langvarig samarbeid mellom de norske miljøene for rehabilitering ved traumatisk hjerneskade er utgangspunktet for denne studien. Samarbeidet har ført til publisering av en rekke artikler om emnet. Denne er gjennomført i samarbeid med Joseph T. Giacino ved Spaulding Rehabilitation Hospital og Harvard Medical School i Boston. Han er en av verdens ledende forskere på bevissthetsforstyrrelser etter hjerneskade.

\section{Lise Mørkved Helsingen}

Tidsskriftet

\section{Frank Becker}

Sunnaas sykehus

\section{Litteratur}

1. Løvstad M, Andelic N, Knoph R et al. Rate of disorders of consciousness in a prospective population-based study of adults with traumatic brain injury. J Head Trauma Rehabil 2014; 29: E31-43.
Ordforklaringer

Vegetativ tilstand: Karakteriseres ved våkenhet uten ledsagende bevissthet.

Minimalt bevisst tilstand: Det observeres sikre tegn til bevissthet uten at pasienten har gjenvunnet normal evne til å være bevisst seg selv, sine omgivelser og sin situasjon.

Alvorlig traumatisk hjerneskade: Hjerneskade grunnet traume mot hodet med laveste skår på Glasgow Coma Scale < 8 i løpet av de første 24 timene. 